\title{
Discrepancies in the evaluation of incapacity for work in a patient with epidermolysis bullosa acquisita between public pension fund and occupational medicine expert raise the issue of competencies
}

\author{
Hrvoje Lalić \\ Rijeka University Faculty of Medicine, Rijeka, Croatia \\ [Received in November 2017; Similarity Check in November 2017; Accepted in January 2018]

\begin{abstract}
A 50-year-old female patient suffering from a severe form of epidermolysis bullosa acquisita (EBA) took legal action against the Croatian Pension Insurance Institute (CPII) in an attempt to overturn their assessment that she was no longer capable of working as a seamstress but still capable of doing administrative jobs. Her claim was that she was not capable of doing any job at all. She was first diagnosed EBA in 2000, and the disease progressed slowly with intermittent remissions. In 2012, skin erosions appeared on her feet, followed by the loss of all toenails and lesions and infiltrations on the tongue and oral mucosa. Her whole body was covered in oozing wounds, she was in pain, and parts of her skin would stick to fabric while changing clothes or bandages. The most recent findings showed oesophageal stricture. She can consume only liquid food and is on the waiting list for receiving a feeding tube. The occupational health expert witness confirmed that the patient was generally incapable of work and was fighting her life. The judge and CPII lawyers fully accepted this report and the earlier assessment was overturned. To avoid incompetent assessments of working (in)capacity in the future, CPII and similar institutions should engage occupational medicine specialists to work in their assessment teams.
\end{abstract}

KEY WORDS: court expertise; EBA; incapacity for work; occupational medicine

Epidermolysis bullosa acquisita (EBA) is a very rare acquired autoimmune disease of the skin and mucosa (1). It is characterised by autoantibodies to type VII collagen (C7), a major component of anchoring fibrils that attach the epidermis to the dermis $(2,3)$. The disease is more common in women than in men and can greatly affect their quality of life (4), to the point of rendering the patients not only incapable of performing their everyday work but of taking care of themselves alone (5). A number of countries have recognised how debilitating the disease is and designed protocols for wound dressing and treatment (6). For patients with the severe forms of EBA, some national health systems provide home nursing that includes professional and family care (7). Yet, when public institutions fail to do their job, these patients are left to their own devices.

The aim of this paper is to raise the issue of competencies of public institutions, pension funds, in particular, whose failure to provide proper expertise may aggravate and eventually endanger the lives of severely disabled patients.

\section{CASE REPORT}

Our 50-year-old female patient, seamstress by profession, is the only patient with the EBA diagnosis in

Correspondence to: Professor Hrvoje Lalić, MD, PhD, Brentinijeva 5, 51000 Rijeka, Croatia, E-mail: hlalic@inet.hr
Rijeka and one of the few registered patients receiving treatment in Croatia. Her disease, diagnosed by a dermatologist in 2000, began with skin erythema and erosions that spread from the hands to the whole body (Figure 1). The skin became very fragile and prone to bleeding, even at the slightest pressure. She lost the sensation in her fingers, lost nails on three of her fingers, and all nails on her toes. The nails were replaced by atrophied skin prone to bleeding. The gluteus region was chronically damp, infected, and inflamed, especially in the crease area with permanent skin contact, which made it impossible for the patient to sit for longer stretches of time. She also had difficulties speaking, as her tongue and oral mucosa were covered with white deposits, infiltrations, and small lesions. She ran a persistent risk of respiratory infections and spreading them to her colleagues at work.

Changing clothes and bandages became extremely painful because the fabric would stick to the skin and oozing wounds. By 2012, the patient could no longer cope with her work at dressmaker's. At that point, her family physician referred her to the Croatian Pension Insurance Institute (CPII), the national public pension fund manager, to asses her work capability. The CPII experts decided that she could no longer work in her profession, do any lifting, use scissors, touch cloth, or expose herself to direct sunlight, but that she was capable of performing administrative jobs. 


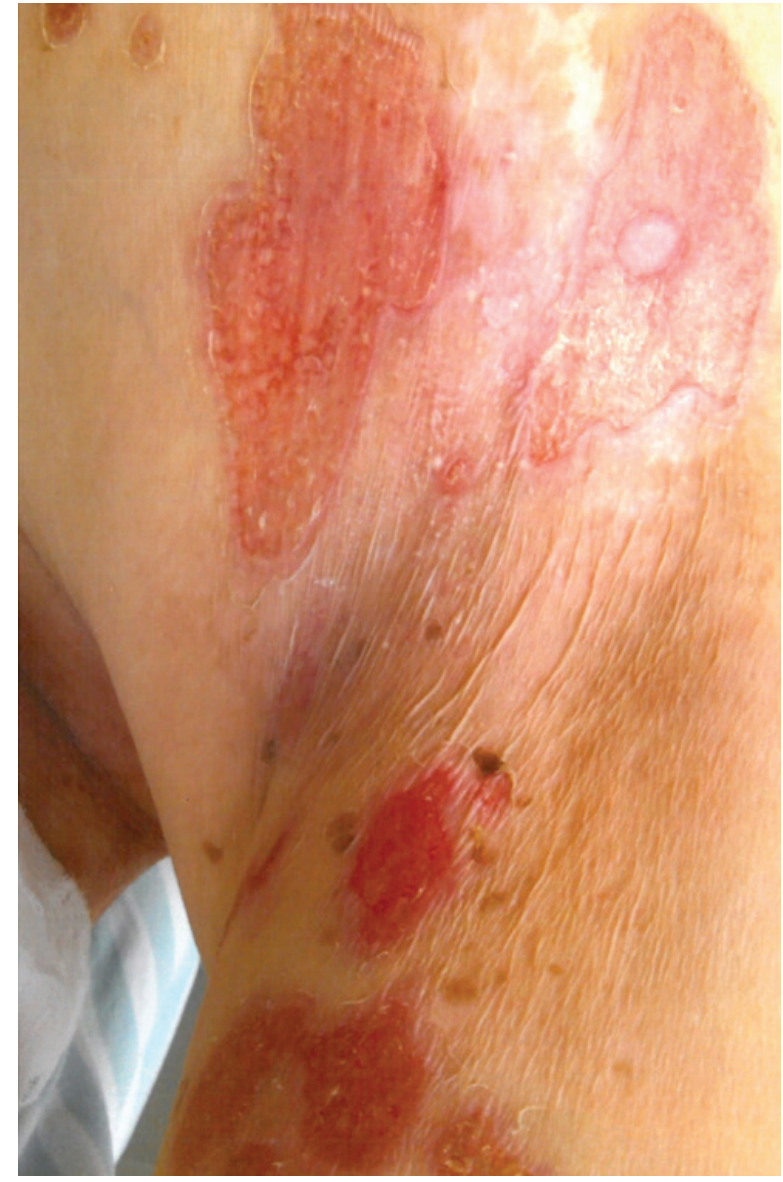

Figure 1 Epidermolysis bullosa acquisita in our 50-year-old female patient showing multiple skin erosions and lesions

Dissatisfied with this evaluation, the patient first filed a complaint to local CPII in Rijeka to review their decision, arguing that she was incapable of any kind of work, administrative included. When the complaint was rejected, she brought the issue before the central CPII in Zagreb, but the first assessment was confirmed in 2017. It took CPII five years to do that! Without further ado, our patient took legal action as an act of desperation by filing a lawsuit against CPII.

In the meantime between the CPII assessment in 2012 and the hearing at court in 2017 , her condition had worsened.

Because of the corticosteroid therapy the patient developed osteopenia and osteoporosis, which eventually lead to the spontaneous pectoral bone fracture (8). Furthermore, since 2012, the disease spread to the oral cavity, manifesting itself with tongue and cheek mucosal infiltrations and wounds. In 2017, she had been having difficulties swallowing. Oesophagoscopy showed oesophageal stricture accompanied by erythema (Figure 2). Her internal medicine physician diagnosed dysphagia, whose association with EBA has already been reported in literature (9), and recommended the use of a feeding tube. For now, the disease has not advanced to the bowels, but this risk is real, as EBA is often accompanied by Crohn's disease (10). The patient also has microcytic anaemia, which is currently treated and monitored by a haematologist. A similar comorbidity has been reported by Yan et al. (11). Laboratory tests showed no other abnormalities.

At the hearing, the occupational medicine expert witness confirmed the patient's claim that she was incapable of any kind of work, based on the disputed health files from 2012. He also established that the CPII experts misconceived EBA as an allergic skin disease instead of seeing it for what it is: a rare and debilitating autoimmune disease that has taken its severe form in our patient. The court swiftly ruled in the claimant's favour, overturning the CPII assessment.

\section{DISCUSSION}

Despite a number of treatments, such as colchicine and immunoglobulin therapy, the disease had progressed rapidly in our patient over the last five years, spreading to oral mucosa and causing oesophageal stricture, but her condition in 2012 was already such to grant her full incapacity benefits. Another debilitating condition, also related to EBA, is the severe osteopenia and osteoporosis. Even commuting to work bears an increased risk of injuries with fatal consequences.

However, the CPII experts have overlooked all these implications, which raises a number of important questions. First and foremost, are the CPII experts competent enough to assess working (in)capacity? Currently, CPII uses the expertise of specialists in physical medicine, orthopaedics, family medicine, and psychiatry, none of whom is specialised in occupational health or competent to assess working (in)capacity in every patient (12). This absence of occupational health specialists in CPII teams is most likely the main reason why our patient's disability was assessed so poorly.

Another very important reason may be the CPII's restrictive approach to granting its clients their incapacity benefits due to economic recession. Over the last twenty years, we have witnessed two extremes: a period when disability pensions were granted almost indiscriminately, followed by recession, when even the persons who are seriously disabled have difficulties obtaining what is rightfully theirs. Committees assessing disability tend to keep patients at work for as long as possible. This often results in long sick leaves and eventually lawsuits, which overflow our courts (13).

Our patient eventually received some sort of moral satisfaction and incapacity benefits, so that she can receive treatment and help at home (14), but at what personal cost?

To avoid similar cases in the future, CPII and similar institutions should include occupational health specialists in their expert teams. By doing so, not only will they grant patients fair treatment and benefits they are entitled to without delay, but they will also save themselves the embarrassment and considerable lawsuit expenses in the long run. 

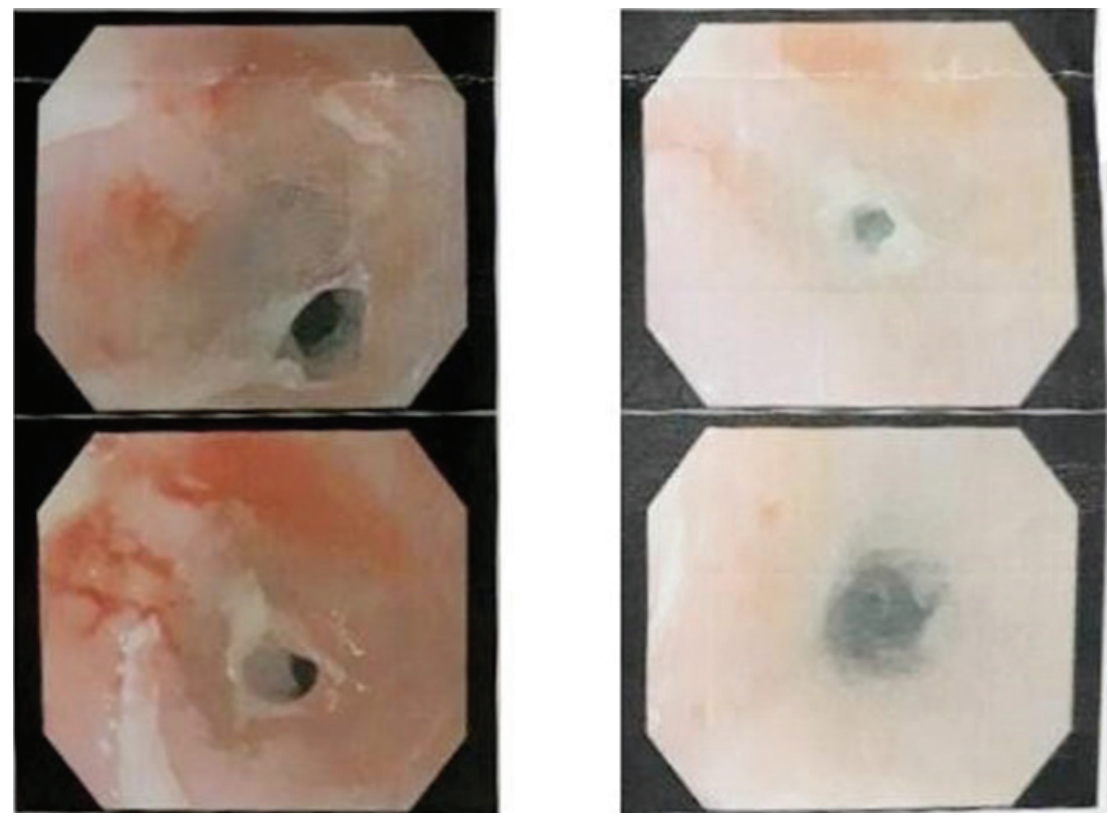

Figure 2 Endoscopy report of oesophageal oedema and obstruction. Taken on 11 August 2017 (courtesy of the Department of Gastroenterology, Clinical Hospital Centre Rijeka)

\section{Acknowledgements}

My deepest gratitude goes to our patient, who gave her informed consent to the publication of this case report.

\section{Conflicts of interest}

None to declare.

\section{REFERENCES}

1. Amber KT, Murrell DF, Schnidt E, Joly P, Borradori L. Autoimmune subepidermal bullous diseases of the skin and mucosae: clinical features, diagnosis, and management. Clin Rev Allergy Immunol 2017; doi: 10.1007/s12016-017-86334 [Epub ahead of print]

2. Esposito S, Guez S, Manzoni F, Bosco A, Rigante D. Epidermolysis bullosa and the partnership with autoimmunity: what should we assimilate? Immunol Res 2015;61:63-9. doi: 10.1007/s12026-014-8583-3

3. Gupta R, Woodley DT, Chen M. Epidermolysis bullosa acquisita. Clin Dermatol 2012;30:60-9. doi: 10.1016/j. clindermatol.2011.03.01

4. Zhao CY, Murrell DF. Autoimmune blistering diseases in females: a review. Int J Dermatol 2015;1:4-12. doi: 10.1016/j. ijwd.2015.01

5. Sebaratnam DF, Hanna AM, Chee SN, Frew JW, Venugopal SS, Daniel BS, Martin LK, Rhodes LM, Tan JC, Wang CQ, Welsh B, Nijsten T, Murrell DF. Development of a quality of life instrument for autoimmune bullous disease: the Autoimmune Bullous Disease Quality of Life questionnaire. JAMA Dermatol. 2013; 149(10):1186-91. doi: 10.1001/ jamadermatol.2013.4972.

6. Stevens LJ. Access to wound dressing for patients living with epidermolysis bullosa - an Australian perspective. Int Wound 2014;11:505-8. doi: 10.1111/j.1742-481X.2012.01116.x
7. Stevens LJ, McKenna S, Marty J, Cowin AJ, Kopecki Z. Understanding the outcomes of a home nursing programme for patients with epidermolysis bullosa: an Australian perspective. Int Wound J 2016;13:863-9. doi: 10.1111/ iwj.12394

8. Den Uyl D, Bultink IE, Lems WF. Advances in glucocorticoid - induced osteoporosis. Curr Rheumatol Rep 2011;13:23340. doi: 10.1007/s11926-011-0173-y

9. Pawar SV, Mohite AR, Surude RG, Rathi PM, Nayak CS. Epidermolysis bullosa acqusita associated with dysphagia and stricture of esophagus. Indian J Dermatol Venerol Leprol 2016;82:717-9. doi: 10.4103/0378-6323.190846

10. Russo I, Ferrazzi A, Zanetti I, Alaibac M. Epidermolysis bullosa acquisita in a 17-year-old boy with Chron's disease. BMJ Case Rep 2015; pii: brc2015210210. doi: 10.1136/ bcr-2015-210210

11. Yan TM, He CX, Hua BL, LI L, Jin HZ, Liu YH, Zuo YG. Coexistence of acquired hemophilia A and epidermolysis bullosa acquisita: Two case reports and published work review. J Dermatol 2017;44:76-9. doi: 10.1111/13468138.13546

12. Wagrowska-Koski E, Rybacki M. Identyfikacja najczęściej występujących problemów w orzekaniu o niezdolności do pracy dla celów rentowych na podstawie działalności ekspertyzowej przychodni chorób zawodowych w latach 2005-2007 [Identification of the most common problems and mistakes in the medical certification of inability to work for disability pension provision based on the expertise carried out by the Out-Patient Clinic of Occupational Diseases, Nofer Institute of Occupational Medicine, Łódź 2005-2007, in Polish]. Med Pr 2010;61:23-33. PMID: 20437886

13. Lalić H. Expert assessment of war casualties. Med Sci Law 2017;57:47-51. doi: 10.1177/0025802416686465

14. Sebaratnam DF, Frew JW, Davatchi F, Murrell DF. Quality of life measurement in blistering diseases. Dermatol Clin 2012;30:301-7. doi: 10.1016/j.det.2011.11.008 


\section{Evaluacija radne nesposobnosti pacijentice sa stečenom buloznom epidermolizom: neusklađenosti između Zavoda za mirovinsko osiguranje i eksperta medicine rada - otvaranje pitanja mjerodavnosti}

Pacijentica u dobi od 50 godina, oboljela od teškog oblika vrlo rijetke bolesti epidermolysis bullosa acquisita, Upravnom je sudu podnijela tužbu protiv Hrvatskoga zavod za mirovinsko osiguranje (HZMO) tražeći da joj se umjesto profesionalne nesposobnosti za rad prizna opća radna nesposobnost. U praksi to znači da su u HMZO-u zaključili da je pacijentica nesposobna obavljati svoje dosadašnje poslove modne krojačice te donijeli rješenje da je sposobna obavljati druge poslove razine srednje stručne naobrazbe, kao što su administrativni poslovi. Još 2012 . godine pacijentica je dobila kožne mjehure i erozije na stopalima uz gubitak svih nožnih noktiju te rane u usnoj šupljini: na jeziku i sluznici obraza. Rane na tijelu na mnogim su mjestima konfluirale, uz vlaženje i bolove, što se svakodnevnim preodijevanjem pogoršavalo jer bi se odizali i dijelovi slijepljene kože. Isto se događalo pri skidanju zavoja. Tijekom 2017. bolest se je proširila na jednjak i dovela do strikture, zbog čega više ne može uzimati krutu hranu. Smatrajući se potpuno nesposobnom za bilo koji posao, podnijela je tužbu Upravnomu sudu protiv HZMO-a, nakon čega je u spor uključen nezavisni sudski vještak medicine rada, koji je pacijenticu pozvao na pregled. Na temelju pregleda i uvidom u medicinsku dokumentaciju, među ostalim i u novi nalaz strikture jednjaka, zaključeno je sljedeće: pacijentica može uzimati samo tekuću hranu, znatno je smršavjela i bit će pozvana u Kliniku za internu medicinu radi ugradnje sonde za hranjenje. Sudski vještak medicine rada procijenio je da je u slučaju pacijentice koja se više ne bori za lakši posao nego za vlastiti život riječ o potpunoj općoj radnoj nesposobnosti. Sudac Upravnoga suda i odvjetnik Hrvatskoga zavoda za mirovinsko osiguranje prihvatili su bez primjedbi stručno objašnjenje sudskog vještaka medicine rada. Pacijentica je zadovoljna takvim ishodom te je dobila nužna financijska sredstva za daljnje liječenje i pomoć u kući. Da bi se izbjegle neusklađenosti u procjeni radne nesposobnosti pacijenata, javni zavodi za mirovinsko osiguranje i srodne institucije trebaju angažirati stručnjake medicine rada za rad u njihovim timovima. Tako će se prevenirati preopterećenost sudova tužbama neprimjereno procijenjenih pacijenata, uštedjet će se državna i privatna materijalna sredstva $i$, što je najvažnije, spriječiti daljnje neugodnosti i oštećenja zdravlja uistinu bolesnih osoba nesposobnih za posao.

KLJUČNE RIJEČI: EBA; medicina rada; nesposobnost za rad; sudsko vještačenje 